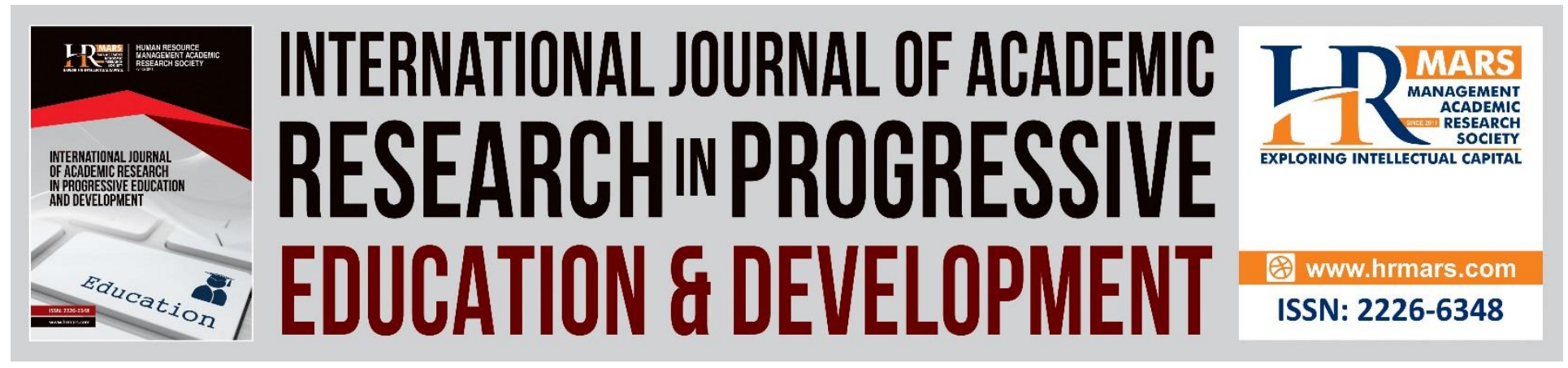

\title{
The Design of Multimedia Interactive Courseware for Teaching Reading to Hearing Impaired Students
}

\section{Syamsinar Abdul Jabar and Aznan Che Ahmad}

To Link this Article: http://dx.doi.org/10.6007/IJARPED/v7-i4/4849

DOI: $10.6007 /$ IJARPED/v7-i4/4849

Received: 25 Aug 2018, Revised: 21 October 2018, Accepted: 11 Nov 2018

Published Online: 17 Nov 2018

In-Text Citation: (Jabar \& Ahmad, 2018)

To Cite this Article: Jabar, S. A., \& Ahmad, A. C. (2018). The Design of Multimedia Interactive Courseware for Teaching Reading to Hearing Impaired Students. International Journal of Academic Research in Progressive Education and Development, 7(4), 223-230.

\section{Copyright: (C) 2018 The Author(s)}

Published by Human Resource Management Academic Research Society (www.hrmars.com)

This article is published under the Creative Commons Attribution (CC BY 4.0) license. Anyone may reproduce, distribute, translate and create derivative works of this article (for both commercial and non-commercial purposes), subject to full attribution to the original publication and authors. The full terms of this license may be seen

at: http://creativecommons.org/licences/by/4.0/legalcode

Vol. 7, No. 4, 2018, Pg. 223 - 230

http://hrmars.com/index.php/pages/detail/IJARPED

JOURNAL HOMEPAGE

Full Terms \& Conditions of access and use can be found at http://hrmars.com/index.php/pages/detail/publication-ethics 


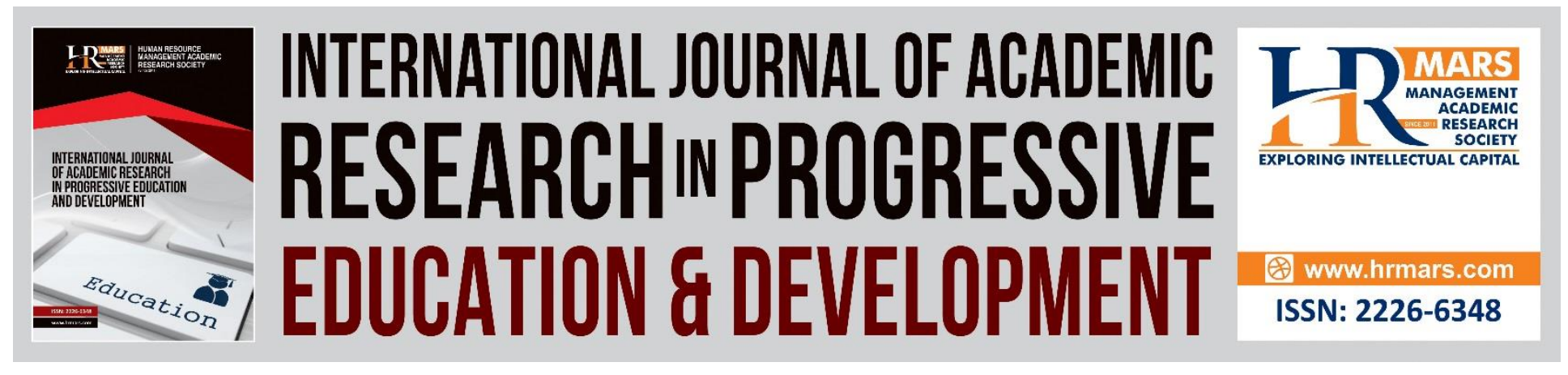

\title{
The Design of Multimedia Interactive Courseware for Teaching Reading to Hearing Impaired Students
}

\author{
Syamsinar Abdul Jabar and Aznan Che Ahmad \\ School of Educational Studies University Sains, Malaysia
}

\begin{abstract}
The purpose of the study was to design multimedia interactive courseware for hearing impaired student. The study focused on comprehensions and competency used of sign language with grade three and four hearing impaired student in Malaysia. The design for this multimedia interactive courseware considered for hearing impaired learners of reading and aimed to minimize cognitive load. The aim of the paper is to describe about designing the multimedia interactive courseware that is developed through user-centered approach.

Keywords: Hearing Impaired, Deaf Learners, Special Educations, Multimedia Learning, Courseware

Introduction

There are more than 70 million people in the world suffer hearing impaired. According to National Deaf Children's Society (2015), the number of deaf children is 32 million. These children deserve to have a quality education same as hearing children. Realizing that situation, this studies will indicate the factors those could assist the hearing impaired students in their learning to read process. Hearing impaired students frequently experience difficulties in reading (Kyle \& Harris, 2010) and writing (Antia et al. 2005). The challenges among hearing impaired students in reading is due to inability to hear the spoken words (Mayer \& Leigh, 2010; Nicholas \& Geers, 2006).

In a study of reading comprehensions achievement for Bahasa Melayu, Abdullah Yusoff (2004) found that hearing impaired students level was substantially lower than their hearing peers. They also show poor achievement on writing (Abdullah Yusoff \& Che Raabiah, 2004). In Malaysia, there are two types of communications methods used by hearing impaired people which is Kod Tangan Bahasa Malaysia (KTBM) and Bahasa Isyarat Malaysia (BIM). KTBM is always used in teaching the hearing impaired students in school. But for the daily communications, the hearing impairment people used BIM rather than KTBM. The use of KTBM as a communication tools to teach reading among hearing impaired students is more practical because of the codes used in KTBM follow the grammar rules of bahasa Melayu (Kementerian Pelajaran Malaysia, 1981).
\end{abstract}


Vol. 7, No. 4, 2018, E-ISSN: 2226-6348 @ 2018 HRMARS

The use of multimedia as a learning tools is widely spread in globalization era nowadays. It is currently growing rapidly throughout the world. Multimedia is one of the learning media that utilizes a special device in the form of animation, image, text and audio (Khanif Thoifatul Maulidah et al. 2018). According to (Mayer, 1997) multimedia is computer utilization in creating and combining text, graphics, audio, video and animation by combining various features that allows users to navigate, interact, create and communicate.

Multimedia has a potentially significant role to play in improving reading achievement among hearing impaired students. Past researcher has used computer-based interventions with hearing impaired students on areas such as grammar (Cannon et al. 2011), narrative retelling (Passig \& Eden, 2010; Beal-Alvarez \& Easterbrooks, 2013), vocabulary and comprehension (Hamilton, 2012), reading comprehension (Gentry et al. 2004; Hoffman \& Wang, 2010; Nikolaraizi et al. 2013) and word-picture matching (Reitsma, 2008). Even though all the studies show the positive results to increase reading achievement among hearing impaired students, but the gaps is still there. The design of the multimedia in terms of cognitive load is still lack in the literature.

According to Techaraungrong et al. (2017), multimedia learning should therefore be aimed at minimizing cognitive load. To minimize load, designers can draw on what Mayer and Moreno (2003) referred to as load-reducing methods. In this study, researcher will focus on the design of multimedia interactive in terms of meeting the special needs of the hearing impairment students.

\section{Methodology}

This study use quasi-experimental method. The quasi-experimental method was employed, in order to examine the effectiveness use of multimedia and multimedia interactive for teaching reading to hearing impaired students.

\section{PARTICIPANTS}

The ten hearing impaired students involved in the prototype testing were in year three and four (age 9-10) from one school in the north of Malaysia. Three specialist participated in the design and creation of the multimedia. One programmer was employed in the creation of multimedia courseware. His role was to transform the storyboards created by the researcher into multimedia. This study also included two specialist in multimedia design. The two specialists are lecturers in a Faculty of Art, Computing and Creative Industry where one of them is a professor. Their role was to evaluate the multimedia in terms of interface and overall multimedia design. They also provided input and advice into the design of the tests. Three teachers also participate at this stage. Their role are to evaluate the content of the courseware and advice in term of the accuracy of the sign language use in the video.

\section{PROCESS}

The design of this multimedia interactive courseware involving five phases according to ADDIE Model. The phases are described as below:

Phase 1: Analyses of the student

In this study, the first step is to identify the individual differences such as level of deafness, family deaf status, age and student existing knowledge on reading comprehension. Despite all the 


\section{INTERNATIONAL JOURNAL OF ACADEMIC RESEARCH IN PROGRESSIVE EDUCATION AND DEVELOPMENT}

Vol. 7, No. 4, 2018, E-ISSN: 2226-6348 @ 2018 HRMARS

characteristic that has been identified, only two aspect were covered in the evaluation. The two aspect are level of deafness and family deaf status. This multimedia interactive courseware will be used in the subject of Bahasa Melayu for standard three and four only. All the student in this study must be able to use a computer and has a knowledge using bahasa Melayu.

Phase 2: Design prototype

Second phase in this study is designing the multimedia interactive prototype. At this phase, researcher design the prototype according to: (1) instructional design, (2) interface design, (3) interaction and navigation design and information design. After designing the storyboard, researcher met with the programmer to create a prototype of the multimedia interactive courseware. Researcher also give the courseware name as Koswer Multimedia Interaktif Bahasa Melayu or KoMIBM. Example of the storyboard shown in Figure 1.

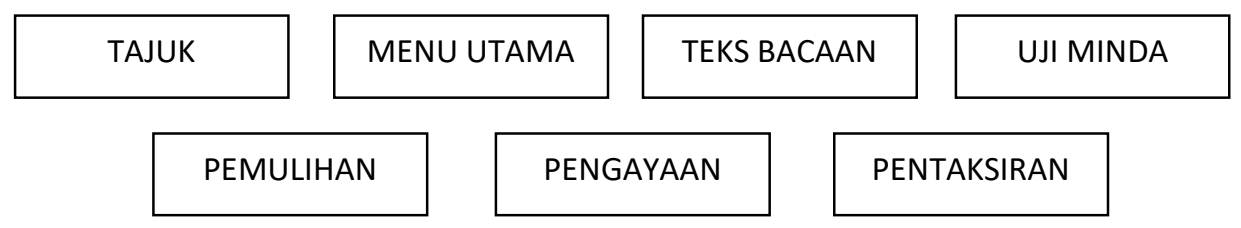

Figure 1. Storyboard

The design of the courseware will meet the needs of reading comprehensions to the hearing impaired students. With this courseware, researcher hope that the hearing impaired students can understands the text and also can learn sign language in the case of this study was Kod Tangan Bahasa Melayu (KTBM).

Phase 3: Developed

In this third phase, researcher will discuss on elements that has to be consider to develop this multimedia interactive courseware. All the elements include in this study were discuss in Table 1. 
INTERNATIONAL JOURNAL OF ACADEMIC RESEARCH IN PROGRESSIVE EDUCATION AND DEVELOPMENT

Vol. 7, No. 4, 2018, E-ISSN: 2226-6348 @ 2018 HRMARS

Table 1. Elements in developing multimedia interactive courseware (KoMIBM)

\begin{tabular}{|l|l|}
\hline Element & \multicolumn{1}{|c|}{ Explanations } \\
\hline Texts & $\begin{array}{l}\text { Texts used in this courseware are simple and easy to understand. } \\
\text { The fonts used is Comic San MS with size 44. For each main title font } \\
\text { size used is 48. Each words in the texts were coloured black and red } \\
\text { to represent the suku kata in bahasa Melayu. }\end{array}$ \\
\hline Graphic and illustration & $\begin{array}{l}\text { Format graphics and illustrations are in form of JPEG and GIF. The } \\
\text { cartoon illustrations used in this study is suitable for students in } \\
\text { primary school. }\end{array}$ \\
\hline Video & $\begin{array}{l}\text { The video used in this study is to teach KTBM to the hearing } \\
\text { impairment students. The format was in MP4 so that everyone who } \\
\text { used this courseware can easily accessed the video using any types } \\
\text { of media. }\end{array}$ \\
\hline Multimedia integrations & $\begin{array}{l}\text { The integrations of all media in this study were using Ispring Suite } \\
\text { Ver.8. }\end{array}$ \\
\hline
\end{tabular}

Phase 4: Implementation

Implementation in contexts of ADDIE Model referring to design and development of learning material that already prepared and will implement according to the student's needs. Normally, this implementation phase will be done after the process of analysis is identified. This phase is to evaluate the effectiveness and detected problems that occur during the design and development phase. The process involved a few students and teacher that meet a criteria in the analysis phase.

Phase 5: Evaluate content and multimedia prototype

The evaluation by content experts and multimedia experts were done to propose suggestions for the prototype. The content experts were selected among teacher who teach in deaf classes for more than 10 years of experience. In this study, three teachers were selected. The content experts propose suggestions in four categories: (1) instructional design, (2) contents, (3) user control and (4) technical. The multimedia experts were two lecturers which propose suggestions in multimedia design and interactive design. The final courseware is shown in Figure 2 below.

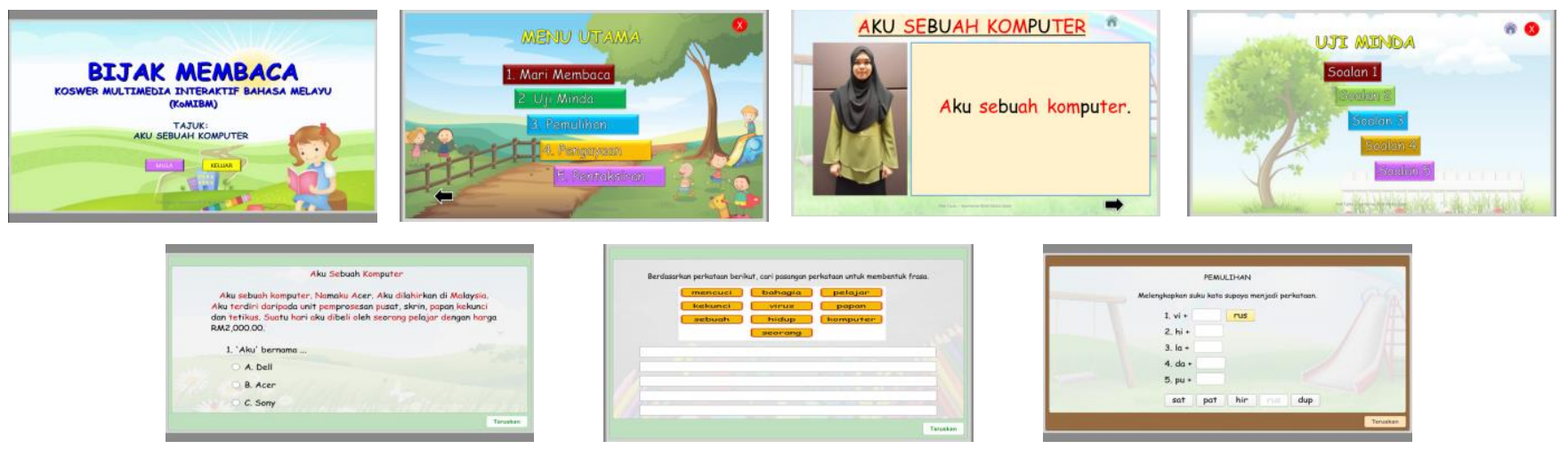

Figure 2. Final courseware 


\section{Conclusions}

Nowadays, research in multimedia learning is widely spread across the globe. According to Nikolaraizi (2012), the use of multimedia software is believed can enrich conventional printed text with visual aids and thus provide deaf children with a scaffold that can be exploited to enhance their access to reading comprehension and also increase their motivation for reading. This paper proposes the design of multimedia courseware in teaching reading in bahasa Melayu to the hearing impaired students. The development of this multimedia courseware is in accordance with hearing impaired students' needs to learn and understanding bahasa Melayu as well as Kod Tangan Bahasa Melayu (KTBM). However, the design of texts and visual aids and the allocation in this multimedia interactive courseware require the consideration and integration of relevant background theory and research, to ensure that the reading needs of hearing impaired students are best accommodated. This courseware were design to address some of the difficulties that hearing impaired student's experience such as not mastering the use of KTBM. The texts were design with the present of KTBM videos. This videos are included to bridge hearing impaired students KTBM knowledge with the print form of bahasa Melayu, and also to provide an alternative form of text parts that might not be easily understood. The placement of the videos and texts in the courseware is based on multimedia design principles, which is not overload readers cognitive capacity but help them mentally integrate information from the text and visual resources. From this study, it is expected that researcher and developers can further develop the leaning media on the next material competence by multiplying the subjects of research and research area.

\section{Corresponding Author}

Syamsinar Abdul Jabar PhD Scholar

Universiti Sains Malaysia

Email: syamsinar@fpm.upsi.edu.my.

\section{References}

Yusoff, A. (2004). Bahasa Melayu dalam kalangan pelajar pekak. Jurnal Dewan Bahasa Jun, 41 (6), 36-41.

Yusoff, A. \& Che, R. M. (2004). Penguasaan Bahasa Melayu dalam kalangan murid pekak: suatu sorotan dari perspektif linguistik. Jurnal Dewan Bahasa, Dis 2004, 639-680.

Antia, S., Reed, S., \& Kreimeyer, K. (2005). The written language of deaf and hard of hearing students in public schools. . Journal of Deaf Studies and Deaf Education, 10(3), 362-377.

Beal-Alvarez, J., \& Easterbrooks, S. (2013). Increasing children's ASL classifier production: a multicomponent intervention. American Annals of the Deaf, 158(3), 311-333.

Cannon, J.E., Easterbrooks, S.R., Gagne, P., \& Beal Alvarez, J. (2011). Improving DHH student's grammer through an individualized software program. Journal of Deaf Studies and Deaf Education, 16 (4), 437-457. 
INTERNATIONAL JOURNAL OF ACADEMIC RESEARCH IN PROGRESSIVE EDUCATION AND DEVELOPMENT

Vol. 7, No. 4, 2018, E-ISSN: 2226-6348 @ 2018 HRMARS

Gentry, M. M., Chinn, K. M., \& Moulton, R. D. (2005). Effectiveness of multimedia reading materials when used with children who are deaf. American Annals of the Deaf, 149 (5), 394402.

Hamilton, H. (2012). The efficacy of dictionary use while reading for learning words. American Annals of the Deaf, 157, 358-372.

Hoffmann, M., \& Wang, Y. (2010). The use of graphic representations of sign language in leveled texts to support deaf readers. American Annals of the Deaf, 155 (2), 131-136.

Kementerian Pelajaran Malaysia. (1985). Komunikasi Seluruh Bahasa Malaysia Kod Tangan Jilid 1. Kuala Lumpur: Dewan Bahasa dan Pustaka.

Kyle, F., \& Harris, M. (2010). Predictors of reading development in deaf children: A 3 year longitudinal study. Journal of Experimental Psychology, 107(3), 229-243.

Mayer, C., \& Leigh, G. (2010). The changing context for sign bilingual education programs: Issue in language and the development of literacy. International Journal of Bilingual Education and Bilingualism, 13, 175-186.

Mayer, R. (1997). Multimedia learning: are we asking the right questions? Educational Psychologist, 38, 1-19.

Mayer, R.E., \& Moreno, R. (2003). Nine ways to reduce cognitive load in multimedia learning. Educational Psychologist, 38 (1), 43-52.

National Deaf Children's Society. (2015). About Deaf Children Worldwide. Retrieved from http://www.deafchilworldwide.info/about us/.

Nicholas. J.G., \& Geers, A.E. (2006). The process and early outcomes of cochlear implantation by three years of age. In P.E. Spencer \& M. Marschark (Eds.), Advances in the Spoken Language Development of Deaf and Hard-of-Hearing Children (pp. 271-297). New York, NY: Oxford University Press.

Nikolaraizi, M., \& Vekiri, I. (2012). The design of a software to enhance the reading comprehension skills of deaf students: An integration of multiple theoretical persepctives. Education Information Technology, 17, 167-185.

Nikolaraizi, M., \& Vekiri, I. (2013). Investigating deaf student's use of visual multimedia resources in reading comprehension. American Annals of the Deaf, 157 (5), 458-473.

Passig, D., \& Eden, S. (2010). Enhancing time connectives with 3-D immersive virtual reality. Journal of Educational Computing Research, 42(3), 307-325. 


\section{INTERNATIONAL JOURNAL OF ACADEMIC RESEARCH IN PROGRESSIVE EDUCATION AND}

DEVELOPMENT

Vol. 7, No. 4, 2018, E-ISSN: 2226-6348 @ 2018 HRMARS

Reitsma, P. (2008). Computer-based exercises for learning to read and spell by deaf children. Journal of Deaf Studies and Deaf Education, 14 (2), 178-189.

Techaraungrong, P., Suksakulchai, S., Kaewprapan, W., \& Murphy, E. (2017). The design and testing of multimedia for teaching arithmetic to deaf learners. Journal of Educational Information Technology, 22, 215-237. 